\title{
Arthroscopic study of the elbow joint in dog cadavers ${ }^{1}$
}

\author{
Estudo artroscópico da articulação do cotovelo em cadáveres de cães
}

\author{
Angelica Cecilia Tatarunas², Julia Maria Matera ${ }^{3}$ \\ 1. Research from Department of Surgery, Faculty of Veterinary Medicine, São Paulo University (USP), Brazil. \\ 2. MD, Fellow PhD degree, Post-Graduation Program in Surgery, Faculty of Veterinary Medicine, USP, Brazil. \\ 3. PhD, Chairman, Faculty of Veterinary Medicine, USP, Brazil.
}

\begin{abstract}
Purpose: To study the arthroscopic technique of the elbow joint in dog cadavers. The possibility to see the intra articular structures, technical difficulties and complications which occurred during the procedure were analyzed. Methods: ten dog's cadavers (twenty elbow joints) were examined. Both, arthroscopic and instrumental portals were performed on the medial site of joint at caudal and cranial positions, respectively. Results: We could see the totality of the proposed structures. The main complications were cartilage iatrogenic lesion and periarticular infiltration. Conclusion: The elbow arthroscopy in dogs permits detailed intra-articular visualization. The arthroscopic and instrumental portals were simple to be done.
\end{abstract}

Key words: Elbow. Arthroscopy. Cadaver. Dogs.

\section{RESUMO}

Objetivo: Avaliar a técnica artroscópica da articulação do cotovelo em cadáveres de cães quanto às dificuldades técnicas, possibilidade de visualização das estruturas intra-articulares e complicações. Métodos: foram utilizados dez cadáveres de cães (vinte articulações do cotovelo). Os portais artroscópio e instrumental foram confeccionados na face medial da articulação, caudal e cranial, respectivamente. Resultados: Todas as estruturas intra-articulares propostas foram passíveis de visibilização. Complicações consistiram principalmente de lesão iatrogênica de cartilagem e infiltração periarticular. Conclusão: A artroscopia do cotovelo no cão é um procedimento que permite a acurada visualização das estruturas intraarticulares, sendo que os portais artroscópico e instrumental mostraram-se relativamente simples de serem confeccionados. Descritores: Cotovelo. Artroscopia. Cadáver. Cães.

\section{Introduction}

Arthroscopy is a minimally invasive surgical procedure, which permits the visualization of the intraarticular structures by illumination and image magnification ${ }^{1,2}$. Besides arthroscopy in dogs has been described in $1978^{3}$, only in 1993 the first study by using this technique in the elbow joint was published, by Van Ryssen et $\mathrm{al}^{4}$. The arthroscopy is used to perform either diagnosis or treatment of the canine elbow diseases. It makes possible the early detection ${ }^{4}$ of the intra articular modifications that probably would not be recognized during an arthrotomy ${ }^{5}$. Technical difficulties such as obstruction of the field of vision by sinovial villus, joint capsule fragments or hemorrhage, insufficient exposition of the articular cartilage and complications can occur. Also complications including periarticular fluid infiltration, cartilage $e^{1,2,4}$ and neurovascular ${ }^{6,7}$ iatrogenic lesions may take place. The use of arthroscopy in dogs has greatly expanded in the last years. There are some elbow joint diseases that would be benefited by the use of the arthroscopy for the diagnosis and treatment. Due to these facts, the aim of this research was to evaluate the possibility to see the intra articular structures, technical difficulties and complications of the use of the procedure in elbow joint of dog cadavers.

\section{Methods}

Ten dog cadavers (twenty joints) which were referred to the Veterinary Hospital of the FMVZ / USP and that had died by diverse causes were used. The equipment consisted of a 2.7-mm 30-degree, 18-cm length, fore oblique arthroscope1, 4-mm cannula2, sharp and blunt obturator3 and probe. A xenon4 175 cold light source 5, 3-mm and 250$\mathrm{cm}$ fiberoptic light cables6, color monitor7, camera head8 and video camera system 9 were used too. The arthroscopic exam was recorded and registered by using the video printer. After clipping the front limbs, the animal was positioned in lateral recumbence with the limb to be operated downward. The elbow was kept close to the surgery table edge. This position allowed the use of the table edge as a fulcrum for distraction of the joint. The irrigation of the joint was maintained using saline by gravity. The medial approach with both, arthroscopic and instrumental portals was done. 
Firstly, the elbow was palpated to locate the landmarks, which are olecranon, trochlea and medial epicondylus of the humerus. In order to distend the joint, saline was injected inside the joint by using a $25 \times 8$ hypodermic needle inserted in a craniodistal and slight lateral direction, beginning just proximal or adjacent to the anconeus. The joint was filled until moderate pressure was felt by digital touching of the distended joint capsule. The arthroscopic portal was established caudally and distally to the medial epicondyle of the humerus. The thumb was placed on the medial epicondyle and drawn down distally and caudally until the approximate level of the joint was reached. A short incision through the skin and superficial soft tissues was made with a small blade (no. 15). The articular capsule was penetrated with the arthroscope cannula fitted with a sharp obturator. Sequentially, the cannula was substituted by the arthroscope. Valgus stress joint was maintained during this procedure. The instrumental portal was established cranially to the arthroscopic portal by using triangulation technique. A $25 \times 8$ hypodermic needle was inserted perpendicular to the limb and in the same plane of the joint. After the tip of the needle has been visualized by the arthroscope and the positioning being satisfactory, a no. 15 blade was used to make a skin and superficial soft tissues incision directly adjacent to the needle. A blunt trocar was then inserted inside the joint. Difficulties such as in establishing the arthroscopic and instrumental portals and in doing the triangulation technique, as well as the possibility to visualize the intra-articular structures, were observed and registered. Especial attention was paid to the premature removal of the arthroscope and instrument, iatrogenic lesion occurrence and periarticular soft tissue infiltration. The intra-articular alterations observed during the arthroscopic exam were recorded and registered by using the video printer.

\section{Results}

The range of the dogs cadavers weight was $12 \mathrm{~kg}$ to $50 \mathrm{~kg}$ (median: $26,5 \mathrm{~kg}$ ). The range of saline injected to distend the joint before the establishment of the arthroscopic and instrumental portals was 4 to $10 \mathrm{~mL}$. The quantity of saline used was proportional to the weight of the animal. The intraarticular structures visualized in all studied joints were: anconeus (Figure 1), trochlear notch, medial and lateral coronoid process, radial head (Figure 2), trochlea, capitulum and articular capsule. Both, arthroscopic and instrumental portals were established in all studied joints. Difficulty in doing the arthroscopic portal was observed in 6 joints (30\%) and instrumental portal in one joint (5\%). It was difficult to visualize the intra-articular structures in 7 joints $(35 \%)$, as well as to perform the triangulation technique in one joint $(5 \%)$.

${ }^{1}$ Hopkins ${ }^{\circledR}$ Forward Oblique Telescope $30^{\circ}$ - Karl Storz GmbH \& Co ${ }^{2}$ Arthroscope Sheath - Karl Storz GmbH \& Co

${ }^{3}$ Karl Storz $\mathrm{GmbH} \& \mathrm{Co}$

${ }^{4}$ Xenon Spare Lamp, 175W, 15V - Karl Storz GmbH \& Co

${ }^{5}$ Cold Light Fountain Xenon Nova - Karl Storz GmbH \& Co

${ }^{6}$ Fluid Light Cables - Karl Storz GmbH \& Co

Color Monitor - Karl Storz GmbH \& Co

${ }^{8}$ Telecam ${ }^{\circledR}$ Câmera Head - Karl Storz GmbH \& Co

9 Telecam ${ }^{\circledR}$ câmera Control Unit - Karl Storz GmbH \& Co
The premature removal of the arthroscope occurred from 1 to 2 times in 8 joints $(40 \%)$. The same was not associated with the use of the probe in the instrumental portal. Cartilage iatrogenic lesion was detected in all examined joints. They were localized on the trochlear notch $(n=2)$, medial coronoid process o the ulna $(n=19)$, trochlea $(n=8)$ and capitulum $(n=3)$ (Figure 3$)$. The lesions detected in the course of arthroscopic exam were fibrillation on the trochlear notch in 4 joints $(20 \%)$, on the medial coronoid process of the ulna in one joint (5\%) (Figure 4), on radio head in 2 joints $(10 \%)$ and on capitulum in one joint $(5 \%)$. The radio head showed chondromalacia in two joints $(10 \%)$ and fissure in one joint (5\%). Superficial cartilage roughness was remarked in 2 joints $(10 \%)$ on the radio head, one joint on anconeus and one joint on capitulum. Sinovial hyperplasia was noted in 4 joints $(20 \%)$. The periarticular soft tissue infiltration occurred in 14 joints $(70 \%)$.

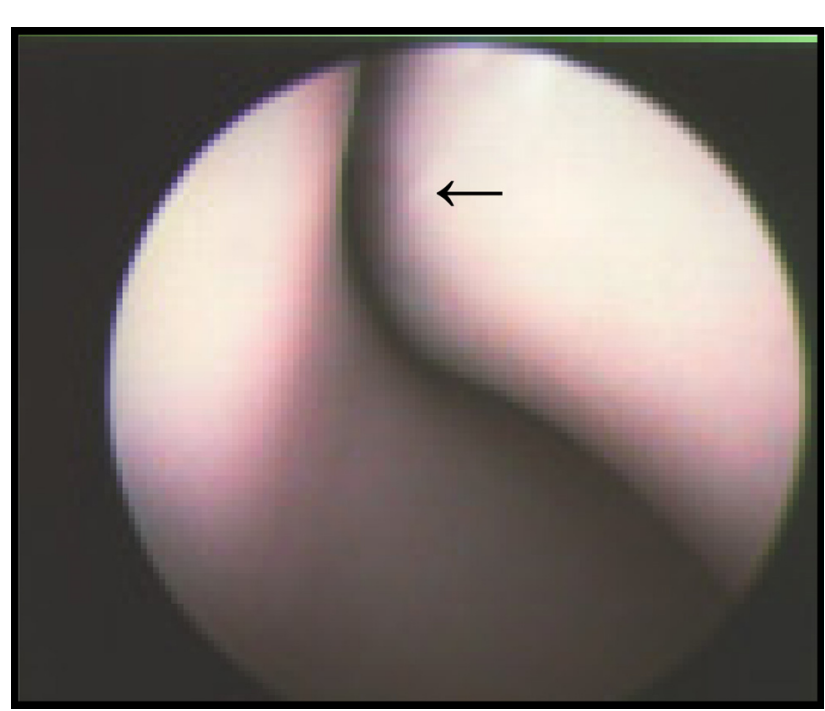

FIGURE 1 - Arthroscopic view of the anconeus process $(\leftarrow)$ in elbow dog cadaver

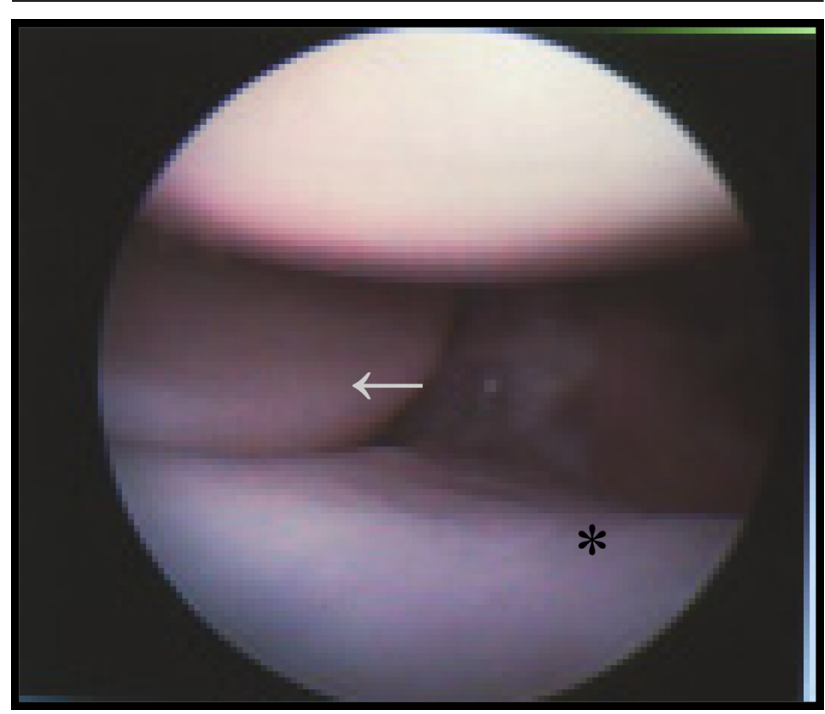

FIGURE 2 - Arthroscopic view of the radial head $(\leftarrow)$ and the medial coronoid process of the ulna $(*)$ in elbow dog cadaver 


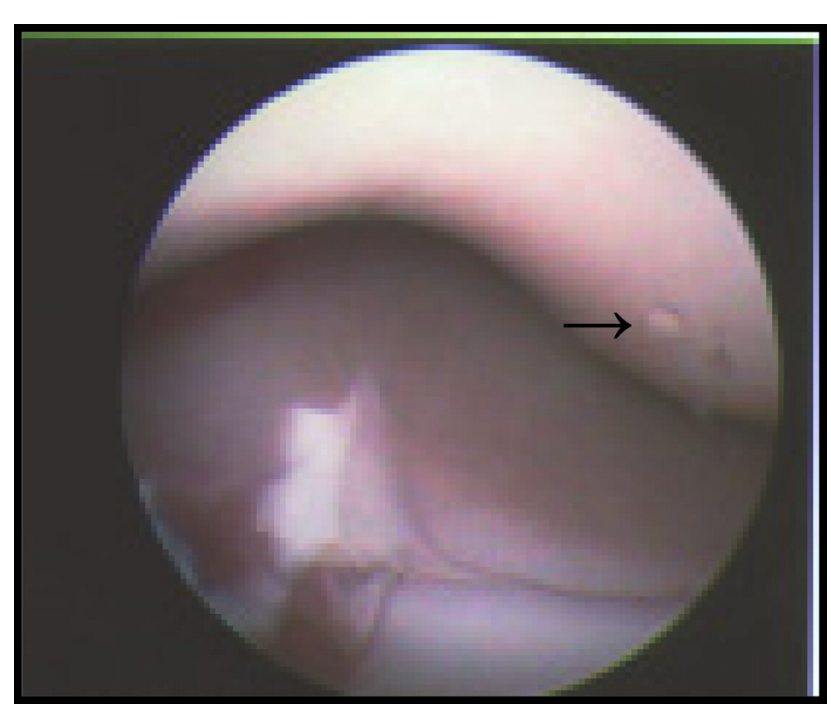

FIGURE 3 - Arthroscopic view of the superficial cartilage iatrogenic lesion $(\rightarrow)$ on capitulum in elbow dog cadaver

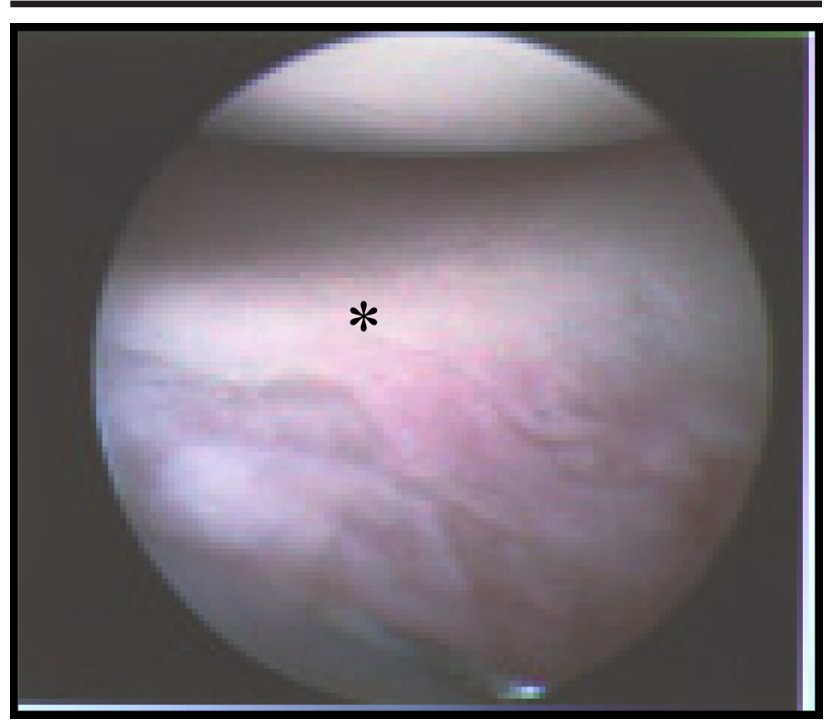

FIGURE 4 - Arthroscopic view of cartilage fibrilation (*) and chondromalacea $(*)$ on the medial coronoid process of the ulna in elbow dog cadaver

\section{Discussion}

The elbow joint is composed of the distal humerus, proximal radius, and proximal ulna. The primary movements of this joint are flexion and extension, but supination and pronation are also possible. Only tiny lateral movements are plausible in canine elbow joint due to the presence of strong collateral ligaments and the protusion of the anconeus process inside the trochlear notch ${ }^{8}$. Therefore, during the elbow arthroscopy it is important to do some specific manipulations in order to promote the opening of the intra articular space ${ }^{1,2,5}$. In this study the joint was kept close to the surgery table edge, which allowed the use of the table edge as a fulcrum for distraction of the joint and to perform the valgus stress. The lateral ${ }^{9}$ and medial ${ }^{1,2,4,5}$ approaches are described in the literature for the elbow arthroscopy in dogs. Due to the fact of the capital elbow diseases in dogs being localized on the intra-articular structures of the medial side, this approach was chosen in this study. The literature recommends to use an $1.9-\mathrm{mm}$ to 2.7-mm arthroscope for the canine elbow ${ }^{2,4,5,9}$. In this research all intra articular structures of the elbow could be observed by using 2.7-mm arthroscope. In spite of this, the use of a smaller arthroscope would probably make easier to introduce the arthroscope cannula during the portal establishment and move the arthroscope inside the joint. Excess of liquid initially injected inside the joint to distend it can cause the rupture of the articular capsule, and promote the extravasation of fluid into the tissues surrounding the joint. Consequently it can be difficult to localize the landmarks for the arthroscopic or instrumental portal establishment ${ }^{2}$. In this research, the quantity of fluid injected inside the joint in the beginning of the procedure was subjectively determined by digital palpation. This maneuver was adequate to avoid the complication above mentioned, as well as to make it easy to identify the joint space, which was important for the arthroscopic portal establishment. The suggested position for the arthroscopic portal is $1 \mathrm{~cm}$ distally and $0,3 \mathrm{~cm}$ to $0,5 \mathrm{~cm}$ caudally to the medial epicondyle of the humerus ${ }^{4,5}$. Because the mentioned measure is not precise for all breed and size of dogs, the arthroscopic portal establishment site was based in predetermined maneuver ${ }^{2}$ by using the epicondyle as a reference, which showed to be satisfactory for this purpose. In this study, the major difficulty associated with the arthroscopic portal establishment was to introduce the arthroscopic cannula with the attached blunt obturator inside the joint. Probably, an arthroscope and cannula smaller those used would be more appropriate. The triangulation technique is suggested for the establishment of the instrumental portal ${ }^{1,2,5}$. In this research, the needle used to make the triangulation technique was inserted perpendicular to the joint and parallel and cranially to the arthroscope ${ }^{2}$. The needle was localized by the arthroscope and the instrumental portal was easily established. Different from $\mathrm{knee}^{3}$, the elbow is the simplest joint to be examined by using arthroscopy in $\operatorname{dogs}^{2}$. All the canine elbow intra-articular structures described in the literature could be seen in this research by using arthroscopy $y^{1,2,45}$. It is important to notice that the most commonly affected area of the joint (medial coronoid, anconeus and trochlea) by disease in growing $\operatorname{dog} \mathrm{s}^{2,5}$ could be clearly observed. The iatrogenic trauma of the articular surface and the extravasation of fluid into the tissues surrounding the joint are complications that should be considered among those of the higher prevalence in the canine arthroscopy ${ }^{2,4}$. This fact was remarked in this research. In spite of the extravasation of fluid into the tissues surrounding the joint has occurred in the majority (70\%) of joints, the quantity of extravasated liquid was not enough to be an obstacle for the procedure. Also, all joints studied showed the cartilage iatrogenic lesion. As the majority of the trauma occurred on trochlea and the medial coronoid process of the ulna probably it was carried during the arthroscopic portal establishment. Therefore, the use of the blunt trocar instead of the sharp trocar, which was used in this research for this purpose, could minimize this event. 
While the nerve injuries carried during the elbow arthroscopy have been studied and recorded in human ${ }^{6,7}$, it was not communicated in dogs at the present time. In the same way, there are important neurovascular structures in the medial side of the canine elbow, which could be injured during the portal establishment. Perhaps the use of the arthroscopy in this joint or the complexity of the procedure that have been done in dogs was not enough to support this problem yet. Thus, a study in dogs evaluating the distance between the neurovascular structures and the arthroscopic approach used in this research should be encouraged.

\section{Conclusion}

The canine elbow arthroscopy permits adequate visualization of intra articular structures. The arthroscopy and instrumental portals establishment by using the proposed technique was easy to perform. A smaller arthroscopy could be more suitable than that adopted in this research.

\section{References}

1. McCarthy TC. Arthroscopy. In: Freeman LJ. Veterinary endosurgery. Philadelphia: Mosby; 1999. p.237-50.

2. Beale BS, Hulse DA, Schulz KS, Whitney WO. Arthroscopically assisted surgery of the elbow joint. In: Beale BS, Hulse DA, Schulz KS, Whitney WO. Small animal arthroscopy, Philadelphia: WB Saunders; 2003. p.50-79.

3. Kivumbi CW, Benett D. Arthroscopy of the canine stifle joint. Vet Rec. 1981;109:241-9.

4. Van Ryssen B, Van Bree H, Simoens P. Elbow arthroscopy in clinically normal dogs. Am J Vet Res. 1993; 54:191-8.

5. Sam AE. Canine elbow joint arthroscopy: introduction and description of technique. Comp Cont Educ. 2000;22:135-45.

6. Papilion JD, Neff RS, Shall LM. Compression neuropathy of the radial nerve as a complication of elbow arthroscopy: a case report and review of literature. Arthroscopy. 1988;4:284-6.

7. Haapaniemi T, Berggren M, Adolfsson L. Complete transaction of the median and radial nerves during arthroscopy release of post-traumatic elbow contracture. Arthroscopy. 1999;15:784-7.

8. Evans HE. Arthrology. In: Evans HE. Miller's anatomy of the dog. Philadelphia: WB Saunders, 1993. p.219-57.

9. Bardet JF. Arthroscopy of the elbow in dogs. Part I: the normal arthroscopic anatomy using the craniolateral portal. Vet Comp Orthop Trauma. 1997,10:1-5.

\section{Correspondence:}

Angelica Cecilia Tatarunas

Av. Prof. Orlando Marques de Paiva, 87

05508-900 São Paulo-SP Brazil

Phone/Fax: (55 11)3091-1219

angelvet@usp.br
Conflict of interest: none

Financial source: Foundation of Support to the Research of the State of São Paulo (FAPESP/04/00299-7)

Received: July 04, 2006

Review: August 11, 2006

Accepted: September 15, 2006

\section{How to cite this article:}

Tatarunas AC, Matera JM. Arthroscopic study of the elbow joint in dog cadavers. Acta Cir Bras. [serial on the Internet] 2006 Nov-Dec;21(6). Available from URL: http://www.scielo.br/acb. 